\title{
Caregiver fatigue and surrogate end-of-life decision making
}

The views expressed in this editorial are those of the author and do not necessarily reflect the position of the publisher.

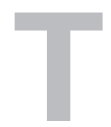

he Supreme Court of Canada ruling in the case of Carter versus Canada (2015 SCC 5) concerns the right of a competent adult to a physicianassisted death if his or her suffering from a grievous and irremediable medical condition is intolerable. Discussions of the ruling have extended the parameters to include competent minors and advanced directives. They may also have altered the way we look at a separate but related end-of-life scenario, withdrawal of lifesupport; the number of anesthetic agents used to cover a patient during the withdrawal of life-support appear to have increased recently.

How is it that all our legal and religious traditions imply that an abhorrence of terminating life is built into civilization, and yet a group of empathetic citizens believe that it may have a role in caring for the seriously ill? Can the decision to end the life of a patient be made impartially?

The clinical situation described in the ruling is rare in the spectrum of end-of-life scenarios. The vast majority of patients will not be able to communicate their consent to termination. Most of us chose our life's companion to be the person who will make our critical decisions when we are incapable. Even though we might hope to guide them by making our wishes known in advance, all decisions are made in their own moment, and upon these delegates we impose the full responsibility of deciding.

While most patients prefer their next-of-kin to be their substitute decision maker, lawyers recommend a third party who will not benefit financially or otherwise by the patient's death. Having a State or hospital committee decide is not acceptable because of past errors made with respect to forced sterilization or memories of Nazi euthanasia programs. However, even an acceptable third party may not be able to remain impartial.

Two doctors would probably be required to determine medical issues in end-of-life protocols. The duplication is an acknowledgement of the subjective nature of such issues and of the risk of conflicts of interest. The strategy of using 2 doctors' opinions originated in France to allow autopsies within 24 hours of death and was later applied to committing patients for psychiatric treatment and to the declaration of brain death for transplantation. ${ }^{1}$
Should the patient's own doctor be 1 of the 2? While a doctor's opinion is unlikely to be influenced by the loss or gain of fees, doctors may share with the patients' representatives a different conflict of interest: the risk of caregiver fatigue.

It is well known that the neural networks stimulated by fear and pain are also activated by observing, or even imagining, the events that cause the fear or the pain. Caregivers suffer with those for whom they care. Loved ones who vicariously experience pain and suffering in ultimately futile care have difficulty coping. Wanting to prevent it from happening again is a natural aspiration. Surgeons try to learn from the experience in order to make the care easier on future patients and to make the outcomes more successful. For others, termination of that phase of life might be considered a better option to prevent futile suffering. There are some diseases, such as advanced amyotrophic lateral sclerosis (ALS), where the prospect of progress appears remote, reinforcing the urge to end the hopeless phase "with dignity."

The stress of care and prolonged exposure to suffering affect family and professional caregivers. Different forms of caregiver fatigue are known, but poorly defined. The ALS Society of Canada believes compassion fatigue occurs when caregivers begin to feel the pain and suffering of the patient so that they lose a sense of themselves and their role in the patient's care. ${ }^{2}$ Sixteen symptoms are listed. Some of these symptoms are similar to those of people with depression, such as difficulty concentrating or sleeping; others are similar to those of people with addiction, such as obsession or difficulties at work. Irritability and difficulty making decisions are hallmarks of compassion fatigue.

Caregiver fatigue may be worsened by the roller coaster of life-saving procedures followed by complications and the inevitable hurdles before recovery. Most surgeons have watched families go from wanting everything done to despair regarding any treatment and then back again - all within hours or days. Surgeons who have invested a lot of effort trying to save a patient risk the same emotional confusion. To build resilience to caregiver fatigue, surgeons need to recognize warning signs and seek a colleague's support in the patient's care. The modern trend to rotating team care inhibits the guidance a surgeon can offer families. All of this may 
result in a premature decision to withdraw life support. It also prevents an impartial decision to terminate life.

The empathy that professional and family caregivers have for seriously ill patients is hard-wired into our brains. The same neural networks are stimulated in third parties reviewing evidence of a patient's suffering. This neurologic mechanism makes us want to end suffering, even if it means terminating life. However, it is the same mechanism that prevents us from making the truly impartial decision necessary to terminate life. An innate understanding of this dilemma is the basis for our customary prohibition on terminating life. It is a dilemma that we may never be able to solve.
Vivian C. McAlister, MD

Coeditor, Canadian fournal of Surgery

Competing interests: None declared.

DOI: $10.1503 /$ cjs. 002616

\section{References}

1. McAlister V. Maimonides's cooling period and organ retrieval. Can 7 Surg 2004:47:8-9.

2. ALS Society of Canada. Compassion fatigue. Available: http://als .ca/sites/default/files/files/Compassion_Fatigue\%281\%29.pdf (accessed 2016 Feb. 25).

\section{La fatigue des aidants et la prise de décisions en fin de vie par autrui}

Les opinions exprimées dans cet éditorial sont celles de l'auteur et ne reflètent pas nécessairement la position de l'éditeur.

La décision de la Cour suprême du Canada dans l'affaire Carter c. Canada (2015 CSC 5) concerne le droit d'un adulte capable de décision à recourir à l'aide médicale à mourir si ses souffrances, dues à un problème de santé grave et irrémédiable, lui sont intolérables. En plus d'avoir élargi les paramètres pour inclure les mineurs capables de décision et les directives préalables, les discussions sur la décision pourraient aussi avoir influencé notre vision d'un scénario de fin de vie distinct mais relié : le retrait du maintien des fonctions vitales. Le nombre d'agents anesthésiants utilisés pour soulager un patient durant le retrait semble d'ailleurs avoir augmenté récemment.

Comment concilier le fait que, d'une part, toutes nos traditions juridiques et religieuses supposent que l'aversion à mettre fin à la vie est intrinsèque à la civilisation et que, d'autre part, un groupe de citoyens empathiques croit que l'aide à mourir pourrait avoir un rôle dans les soins aux personnes gravement malades? Une décision de mettre fin à la vie d'un patient peut-elle être impartiale?

La situation clinique décrite dans la décision survient rarement dans le continuum des scénarios de fin de vie. La vaste majorité des patients ne sont pas en mesure de communiquer leur consentement à mourir, et la plupart désignent leur partenaire de vie pour prendre des décisions essentielles à leur place lorsqu'ils en seront incapables. Même si les patients espèrent guider leurs proches en leur faisant connaître leurs volontés à l'avance, chaque décision doit être prise dans un contexte unique, et c'est sur les épaules de ces délégués que reposera la pleine responsabilité du choix.

Bien que la plupart des patients préfèrent que leur plus proche parent prenne les décisions à leur place, les avocats recommandent de faire appel à un tiers qui ne profitera ni financièrement ni autrement du décès du patient. Par ailleurs, il ne serait pas acceptable de confier ces décisions à l'État ou à un comité d'hôpital en raison des erreurs survenues dans le passé, notamment la stérilisation forcée et les programmes d'euthanasie instaurés sous le régime nazi. Cependant, même un tiers pourrait être incapable de rester impartial.

Les protocoles de fin de vie exigeraient probablement l'intervention de 2 médecins pour cerner les problèmes médicaux. Cette redondance confirme la nature subjective de ces questions et le risque de conflit d'intérêts. Utilisée pour la première fois en France pour rendre possibles les autopsies moins de 24 heures après le décès, la stratégie du recours à 2 médecins a ensuite été appliquée à la décision d'interner des patients pour un traitement psychiatrique et à la déclaration de mort cérébrale aux fins de transplantation ${ }^{1}$. Le médecin du patient devrait-il compter parmi les décideurs? Bien que leur opinion risque peu d'être influencée par la perte ou le gain d'argent, les médecins peuvent partager avec les représentants des patients un autre type de conflit d'intérêts : le risque de fatigue des aidants.

On a déjà démontré que les réseaux de neurones stimulés par la peur et la douleur sont aussi activés par l'observation, ou même l'imagination, d'événements qui 